\title{
BEHAVIORAL AND CULTURAL ACCOUNTS OF CORRUPTION IN THE INTERFACE BETWEEN PUBLIC
} OFFICER AND CLIENT ${ }^{1}$

\section{EXPLICAÇÕE COMPORTAMENTAIS E CULTURAIS DE CORRUPÇÃO NA INTERFACE ENTRE FUNCIONÁRIOS PÚBLICOS E USUÁRIOS}

\author{
TETE KoBLA AGBOtA \\ INGUNN SANDAKER \\ LUCAS COUTO DE CARVALHO \\ KALLIU COUTO, \\ Oslo and Akershus University College of Applied Science, Department of BehaVioral Science, Norway
}

\section{RESUMO}

O presente artigo aplica uma perspectiva analítico comportamental para examinar comportamento corrupto. Com esse artigo, pretende-se atender a um chamado feito há algumas décadas aos analistas do comportamento para estender os interesses e estratégias de sua disciplina a domínios tradicionalmente atribuídos às ciências sociais. Este artigo tem três objetivos: primeiro, examinar a corrupção como fenômeno comportamental e cultural; segundo, alertar a comunidade das ciências sociais para a utilidade das ferramentas conceituais analítico-comportamentais para a investigação da corrupção; terceiro, chamar a atenção de analistas do comportamento para algumas pesquisas sobre corrupção, que é uma das questões mais críticas do século XXI.

Palavras-chave: Corrupção, Contingências, Metacontingências, Práticas culturais, Cultura.

\section{ABSTRACT}

This paper applies a behavior analytic framework to examine corrupt behavior. With this article, we heed to the call made some decades ago to behavior analysts to extend the interests and strategies of their discipline into domains traditionally assigned to the social sciences. This article has three objectives: First, to examine corruption as behavioral and cultural phenomena; Second is to draw the attention of the social sciences community to the potentials of behavior analytic tools to investigate corrupt behavior; Third, to appeal to behavior analysts to direct some research attention to corruption, which is one of the most critical issues of the twenty-first century.

Keywords: corruption, Contingencies, Metacontingencies, Cultural practices, Culture.

\footnotetext{
The authors extend their thanks to M. F. Valdez and N. Reynolds for their proofreading services. We are also immensely grateful to F. Bento, R. Nartey, A. Imam and J. Mensah for their comments. Finally, we wish to thank the anonymous reviewers and Associate-editor, Prof. Aécio Borba, for their insightful and supportive comments. This paper was presented at ABAI Conference in May 2016. Corresponding author: Tete Kobla Agbota, Oslo and Akershus University College of Applied Sciences, Faculty of Health Sciences, Department of Behavioral Science, PB 4 St. Olavs plass, N-0130 Oslo, Norway. Email: tetekobla.agbota@hioa.no.

1 - Neoliberal policies depict the individual as homo economicus, by calling a person a client or a consumer (capable of making rational choices). We use the terms client/user with no other connotation than a person seeking administrative decision or service from a public entity.
} 
One of the major problems confronting the world in the 21 st century is corruption. Corruption is the offering, giving, receiving, or soliciting, directly or indirectly, anything of value to improperly influence the actions of another party (World Bank, 2017). It has detrimental effects on the social, economic, and democratic development of many countries. According to Carson and Prado (2014, p. 4) "corruption consumes between 1.4\% (FIESP, 2010) and 5\% (Época, 2008) [of Brazil's] GDP, translating into economic losses of between $£ 10.5$ billion and $£ 32.9$ billion each year”. This enormous revenue loss is partly the result of either corrupt tax officials who are bribed to reduce corporate taxes for companies, or land officials who are illegally paid by construction companies to avoid zoning laws.

Literature differentiates between two major types of corruptions, petty and grand corruptions, as presented in Table 1. Grand or political corruption is the abuse of office perpetrated by politicians or top-bureaucrats involving huge amounts of money. The use of public funds for political party campaign activities as in the Cardoso's vote-buying case, Mensalão, and Petrobrás scandals, the receipt of illegal payments from the private sector or citizens in exchange for favorable treatment as in Collorgate, Budget Dwarves, Operation Anaconda, Operation Bloodsuckers, and recently Operação Lava Jato are some examples of grand corruption cases in Brazil (Carson \& Prado, 2016). Petty corruption, in contrast, is bribery demanded by a public officer or offered by a client in connection with service delivery in areas such as health, social care, education, or when making administrative decisions such as the issuance of permits and licenses to mention a few (Byrne, 2009). Unofficial payment, speed money, bureaucratic corruption, administrative corruption or street-level corruption are some other labels of petty corruption (Basu, 2011). In the face of rigid and sometimes unnecessary bureaucracy, the cultural phenomenon known as "jeitinho brasileiro" may have impact on how citizens behave during public encounters (the interfaces of public officer and client, where decisions are made on who gets what public goods and services) (Goodsell, 1981). Citizens cut corners, cheat break "predetermined standard, whether in the form of conciliation, cleverness, or ability" (Fernandes, Pezzato, \& Perallis, 2015, p. 28). Petty corrupt behaviors like these may be openly or tacitly applauded in some socio-cultural environments (Power \& Taylor, 2011). Interestingly, the ingrained jeitinho of grand corruption scandals like those in Brazil concerning top-level officials or politicians may cause huge public outcries in spite of the prevalence of petty corruption. Such petty corruption in itself is more likely to be experienced as a big problem by average citizens as it has been reported in Ghana (Agbota, Sandaker, \& Ree, 2015; CDD, 2000). Carson and Prado allege, however, that "the core corruption challenges currently facing
Brazil lie not in street-level, petty corruption, but in systems and institutions that have allowed grand corruption to persist" (2014, p. 31). Thus, despite the prevalence of petty corruption in Brazil, it does not receive the same attention as grand corruption. Regardless of the form (petty or grand), behavioral and cultural corrupt practices may be similar but have different consequences for the individuals and/or the society. Data reported in previous studies reveal that countries with very low frequency of petty corruption have little or no incidences of grand corruption, while those with high incidences of petty corruption tend to have high incidence of grand corruption (Della Porta \& Vannucci, 1999; Uslaner, 2008). Thus, the prevalence of petty corruption in a society may indicate a fertile ground for grand corruption (Della Porta \& Vannucci, 1999; Johnston, 1997; Rose-Ackerman, 1999). Consequently, to eradicate grand corruption, a polity (society, state, or unit of government) must reduce petty corruption, which may appear insurmountable. Because petty corruption may be embedded in socio-cultural practices ${ }^{1}$. Fernandes et al. (2015), assert that jeitinho, as a cultural practice, is employed by Brazilian politicians, companies, and ordinary citizens to obtain benefits or to avoid fiscal obligations such as payment of taxes. In Ghana, the phrase "Everybody chops from his workplace" epitomizes the tacit acceptance of private use and appropriation of government property as a common practice in many governmental agencies (Agbota et al., 2015). Table 2 provides some examples of petty corrupt practices in Brazil and Ghana. Petty corruption could be kickbacks for the award of government contracts, gratuity to public servants upon execution of official duty, nepotism and may have connections with civil servants (Nuijten \& Anders, 2007).

\footnotetext{
${ }^{1}$ The prevalence of petty corruption in poor developing countries has been used to explain the existence and tolerance of grand corruption in these societies. However, despite little or no petty corruption in rich developed countries, where bureaucrats do not ask for bribe and citizens do not give bribes during public encounters, literature is replete with incidences of grand corruption in some developed countries (Golden, 2012). Even though this theme is beyond the scope of this paper, our contention is that the environmental factors (antecedents and consequences) influencing grand corruption may differ in both worlds; but the topographies of behaviors may be characterized by nepotism, favoritism, clientelism and patronage.
} 
Table 1.

A Typology of Corruption Based on Agent Categories (Based on Pedersen and Johansen, 2005, p. 7)

\begin{tabular}{|c|c|c|c|}
\hline Actors & $\begin{array}{l}\text { Corruption - nature or } \\
\text { form }\end{array}$ & $\begin{array}{l}\text { The supply side of } \\
\text { corruption }\end{array}$ & The demand side of corruption \\
\hline \multirow[t]{2}{*}{ Petty Corruption } & Everyday corruption & Individual citizens & $\begin{array}{l}\text { Individual providers of public } \\
\text { services such as: health } \\
\text { personnel, police, teachers }\end{array}$ \\
\hline & $\begin{array}{l}\text { Administrative } \\
\text { malpractices/ } \\
\text { administrative capture }\end{array}$ & $\begin{array}{l}\text { Individuals (clients, } \\
\text { patients and their } \\
\text { dependents, parents, } \\
\text { schoolchildren, drivers, } \\
\text { students, firms etc.) }\end{array}$ & $\begin{array}{l}\text { When administrative regulation } \\
\text { is applied by public officers in } \\
\text { delivery of services or control } \\
\text { like: like health, education, } \\
\text { licensing of vehicles, tax, } \\
\text { revenue and security }\end{array}$ \\
\hline Grand corruption & Political state capture & $\begin{array}{l}\text { Collective economic } \\
\text { actors(special interest } \\
\text { groups or individual } \\
\text { actors) }\end{array}$ & $\begin{array}{l}\text { Politicians (the executive and } \\
\text { parliamentarians) and top } \\
\text { bureaucrats }\end{array}$ \\
\hline
\end{tabular}

Table 2.

Petty Corrupt Practices in Brazil and Ghana.

\begin{tabular}{|c|c|c|}
\hline $\begin{array}{l}\text { Common practices of corruption in Brazil and } \\
\text { Ghana }\end{array}$ & $\begin{array}{l}\text { Malfeasance in the form of kickbacks } \\
\text { during regulator/regulatee interface }\end{array}$ & Income hunters or rent seekers \\
\hline $\begin{array}{l}\text { Cheating or swindling on benefits from the } \\
\text { government (such as unemployment benefits, } \\
\text { pensions and social benefits such as "bolsa } \\
\text { família" in Brazil). }\end{array}$ & $\begin{array}{l}\text { To pay public inspectors/regulators to } \\
\text { renew license even though one's } \\
\text { facility (hotel) does not meet mandatory } \\
\text { requirements. }\end{array}$ & $\begin{array}{l}\text { The purchasing and selling of } \\
\text { goods and services without } \\
\text { demanding or issuing invoice. }\end{array}$ \\
\hline Vote buying by politicians. & $\begin{array}{l}\text { Sealing agreements with regulators or } \\
\text { controllers (This could take place }\end{array}$ & $\begin{array}{l}\text { Giving unauthorized discounts on } \\
\text { business concessions (through a } \\
\text { billing regime that prevents a }\end{array}$ \\
\hline $\begin{array}{l}\text { Officials who ask for money to manipulate public } \\
\text { biddings for bidders. }\end{array}$ & $\begin{array}{l}\text { between public sector and private sector } \\
\text { actors or between two private }\end{array}$ & private sector actor to pay taxes) \\
\hline $\begin{array}{l}\text { Tempering of one's own socio-demographic data } \\
\text { to qualify social benefits (forgery). }\end{array}$ & businesses in the private sector) & $\begin{array}{l}\text { Sale of products with specifications } \\
\text { differing from advertised items }\end{array}$ \\
\hline $\begin{array}{l}\text { Bribing a police officer to avoid a ticket or the } \\
\text { inconveniences of prosecution or court hearing. }\end{array}$ & $\begin{array}{l}\text { Purchasing official and } \\
\text { commercializing confidential material. }\end{array}$ & Selling of fake products. \\
\hline $\begin{array}{l}\text { Nepotism and cronyism - obtaining scholarships } \\
\text { for unqualified wards to universities. Employing } \\
\text { unqualified friends and relatives. }\end{array}$ & $\begin{array}{l}\text { Employee fraud/pilfering } \\
\text { Tax evasion. }\end{array}$ & \\
\hline $\begin{array}{l}\text { Restaurants offering free meals to police officers } \\
\text { or food to health and safety regulators. }\end{array}$ & & \\
\hline
\end{tabular}

Source: Compiled by the authors in 2017 
Irrespective of the type of corruption or the agents involved in corruption, corrupt behavioral topographies may have similar functions. We delineate at least three topographies: (1) when a person or a corporate body offers a public officer a bribe to access licit or illicit services; (2) when a public officer demands a payment (as a condition) to provide licit/illicit services and (3) collusive corruption, when two or more persons condone and connive to flout laws and regulations for personal or organizational gain (Agbota, Submitted; Klitgaard, 1988).

The pervasiveness and persistence of petty corruption during the administrative action and its effects on society have received the attention of the social sciences (Rothstein \& Varraich, 2014). Some social science models explain the persistence of corruption as being a result of individual personality or volition (psychology; Köbis, Van Prooijen, Righetti, \& Van Lange, 2016; Rabl \& Kühlmann, 2008); strategic or rational choices of individuals (economics; Mishra, 2005; Barr \& Serra, 2010; Basu, 2011); political system (political science; Karklins, 2005) and societal norms (sociology and anthropology; Le Vine, 1975). Despite the strength of behavior analytic tools in explaining corrupt behavior, there are very few behavior analytic works on corruption. Recent literature reviews on corruption (e.g., Breit, Lennerfors, \& Lena, 2015; Fein \& Weibler, 2014; Rothstein \& Varraich, 2014) did not refer to any behavior analytic principles of behavior. This lack of references may be an indication of the little interaction between behavior analysis and the social sciences in certain thematic areas (Sandaker, 2006). The present paper applies a behavior analytic framework to examine the environmental events influencing corrupt behavior and practices, by examining the contingencies and metacontingencies that govern or maintain them, rather than explaining corruption in terms of personality traits, political parties, or programs implemented by governments.

With this article, we heed the call made some decades ago to behavior analysts to extend the interests and strategies of their "discipline into domains traditionally assigned to the social sciences" (Malagodi \& Jackson, 1989, p.17). The article has three objectives: First, to examine corruption as behavioral and cultural phenomena. Second, to draw the attention of the social science community to apply the behavior analytic conceptual tools to investigate corrupt behavior. Finally, to appeal to behavior analysts to direct some research attention to one of the most critical issues of the twenty-first century.

\section{Focus on behavior and not labels of behavior}

Honesty, integrity, and dishonesty are some of the concepts used in social sciences literature to explain compliant (integrity) and non-compliant (corrupt) behaviors. By definition, corruption is dishonest behavior in the sense that one abuses an entrusted authority either for personal or organizational gain. However, one should be wary not to use labels to explain behavior. For instance, the statement: "the public official embezzled government funds because he is dishonest or lacks integrity", does not explain causality. From a behavior analytic perspective, honesty and integrity (ethics and morals) refer to certain standards of behavior developed by a culture to promote the survival of that culture (Martin \& Pear, 2009). For the behavior analyst, the explanation of what is honest or dishonest (ethical or unethical) behavior would be sought in the reinforcement and punishment practices of that culture and the reinforcement history of the individual. Within a culture, informal and formal sets of contingencies are selected and become recurrent/embedded as a function of their adaptive value for its members (Couto \& Sandaker, 2016). Public encounters or transactions between a public officer and a client are regulated by rules/laws (Goodsell, 1981), because they are purposive and official, and not private meetings between a public officer and a client. Laws or rules regulating administrative processes enjoins both public officers and clients "to act legally rather than deterred from acting illegally" (Skinner, 1953, p. 345). The intention of the formal rules is to shape/control behavior even when supervision and management are absent (Daniels \& Lattal, 2017). In certain circumstances, an individual may engage in temporal discounting behavior; compromising the laws to produce immediate personal gain, rather than complying with the law for delayed gain for oneself and for the public good. Human behavior can be interpreted as the product of the interplay of three levels of selection: (a) contingencies involved in natural selection (phylogenesis), (b) environmental contingencies that shape individual behavior (ontogenesis), and (c) contingencies involved in selecting a social environment (cultural) (Skinner, 1981). In the ensuing sections, we perform operant (ontogenesis) and metacontingency (cultural) analysis corrupt behavior.

\section{An operant analysis of corrupt behavior}

Behavior analysts invariably submit individual behavior to scientific investigations as either a respondent behavior or an operant behavior or both. Respondent behavior is a behavior in response to specific antecedent stimuli (conditioned or unconditioned). According to Cone and Hayes (1984, p. 26), studying illegal behavior as respondent behavior may sometimes mislead the individual performing the behavior to refer to the antecedent stimulus as the cause of the behavior. An operant analysis investigates the functional relations between behavior and its environmental determinants. As an operant behavior, we define corruption is an illegal verbal or non-verbal behavior of a person who flouts administrative rules and uses his or her control of reinforcers/punishers for personal or organizational gain in connection with the provision or reception of goods and services. Figure 1, an expanded version of the three-term contingency, is used to depict a hypothetical case where a person (client) applies to register a business. Procuring permits and licenses to operate a business in Brazil involves complex and time-consuming 
procedures (e.g., see Brasil, 2007).

For instance, in Brazil it could take up to 180 days to get a permit to operate a business (Brasil, 2007). In this hypothetical case, the client paid a bribe (B), as depicted in the figure above to obtain a permit and it took him/her less than 30 days. Several factors might have engendered this bribery behavior: The client could not wait for 180 days for a permit because it may lead to losing a business opportunity. The long case processing queues and inefficient bureaucracy can create bribery opportunities. Literature on corruption has documented that case processors may deliberately manipulate queues as motivating operations to coerce clients to behave corruptly (Dwivedi, 1990). A setting, environmental factors or events influencing behavior could be open, implying a person has different providers to choose among, or closed, when there is only one provider
(Foxall, 2010). The client in this instance has a closed setting (A1) because officialdom (A2) has a monopoly over the processing of business permits. The broken line of the feedback loop to A1/A2 indicates that the client cannot alter his/her setting. In this case, our client's behavior of paying a bribe is positively reinforced. Being positively reinforced could be one of the possible outcomes of corrupt behavior. $\mathrm{S} /$ he risked the possibility of being caught and may face the rigors of the law (positive or negative punishments). However, in this example, the briber and bribee were not caught. Giving and accepting bribe may become part of their behavioral repertoires (A3 and A4). All things being equal, when faced with similar situations in the future, bribing may be resorted to because it has worked to get things done in the past (reinforcement history) (D).

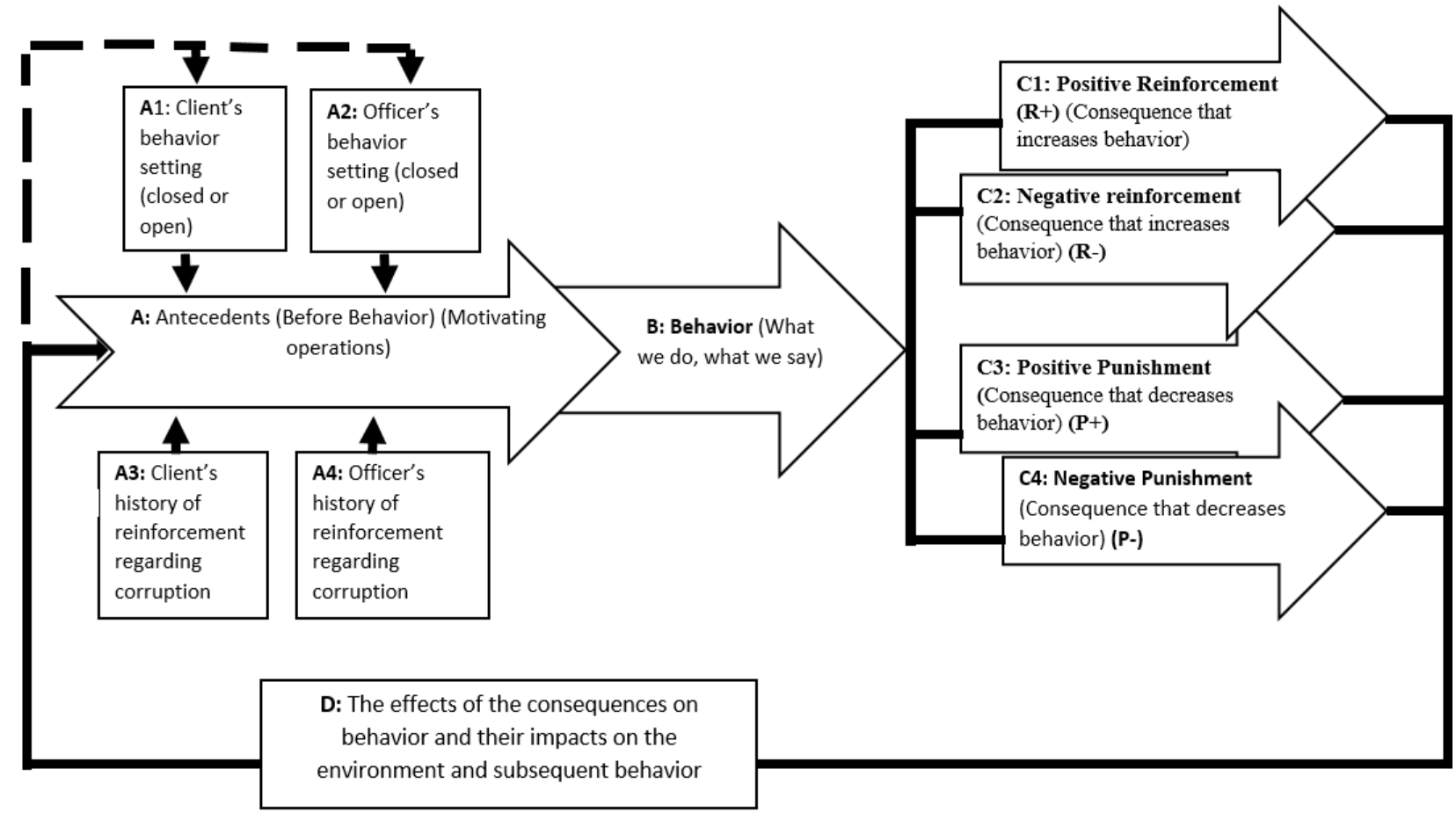

Figure 1. Corrupt behavior - the three-term contingency.

We have briefly examined corruption as an operant behavior. While an operant analysis helps to identify the contingencies controlling the behavior of an individual, we have to keep in mind that there are at least three or more agents/actors (briber, bribe, and oversight) involved directly or indirectly in any corrupt practice. One may lose sight of the interlocking behavioral contingencies and the role of the agents and the institutions involved in producing a fraudulent aggregate product if the researcher performs only an operant analysis in collusive corrupt cases. Therefore, we contend that in any analysis intending to study corrupt transactions, the behavioral interactions between and among individuals and groups of individuals must be examined with the concept of metacontingency (Glenn, 1986; Glenn et al.,
2016) or a system analysis.

\section{Corruption as cultural practice}

Culture is a complex adaptive social system possessing several observed and agreed upon characteristics which are recognizable over time even though members of the system are replaced by new ones (Sandaker, 2009). The corrupt activities of some lawyers, detectives, and judges in Brazil who sold judicial decisions is a case in point of collusive behavior as corrupt cultural practices. We surmise that before the corrupt racket was broken, it took place year in and year out despite the change of personnel (personnel turnover is a common feature of organizations). The persistence of the corrupt practices in spite of new personnel 
is an indication of the existence of culture, which is transmitted from old employees to new employees. Corruption at the interpersonal/systems level is an illegal verbal or nonverbal transaction between at least two people maintained by the joint product of their behaviors. These products, tangible or intangible, could not have been obtained without flouting the rules regulating behavior during the provision of goods or services with or without a receiving system.

\section{Metacontingency analysis: Compliance and non- compliance with rules as an aggregate product in corrupt/incorrupt transactions}

Tersely defined metacontingency as “ [a]contingent relation between (1) recurring interlocking behavioral contingencies (IBCs) having an aggregate product (AP), and (2) selecting environmental events" (Glenn et al., 2016, p. 13). The concept of metacontingency makes the analysis of the behavioral processes of two or more individuals methodologically palpable as a cultural practice (Todorov, 2006). We employ the concept of IBCs here to describe incorrupt (sanctioned) or corrupt (unsanctioned) interactions during public encounters. For instance, a client who applies (supposedly incomplete application) for a business permit may offer a bribe to a public officer ${ }^{2}$ (s) either to speed up the processing of the application or to disregard an incomplete application. The bribe may serve as a discriminative stimulus for the officer's behavior. The officer's response (accepting or rejecting the bribe) may serve as the consequence(s) for the client's response (to give a bribe or not). The outcomes of these exchanges have consequences for the officer as well as the client. Assuming that the bribe is accepted, the client gets his permit granted, and the public officer gets money (bribe), but the aggregate product of client-officer IBCs is an approved business permit granted by not-complying with rules and regulation as depicted in Figure 2.

The granted permit (AP without complying with the stipulated rules regulating the processing of application) did not materialize because of the behavior of a person, but several persons (the briber, bribe, and an oversight person). This is a cooperative action since the emission of a response by one agent depends upon the emission of a response by another agent. For instance, if the client offers bribe after ascertaining the corruptibility of the public officer, probably with a corrupt metaphor (Agbota et al., 2015), the client de facto has provided a discriminative stimulus upon which the public officer can respond (accept the bribe or reject bribe). Similarly, if the officer does not respond (e.g., does not ask for a bribe), the officer does not provide any discriminative stimulus upon which the client can respond (offer bribe).

\footnotetext{
${ }^{2}$ Several departments (officers) may process a business permit. We will use the interaction between an officer and a client.
}

Therefore, corruption takes place only through the concerted effort by the briber and bribee, and possibly an unprincipled oversight, for example, to get an incomplete application approved with timeliness. To sum up, the product or consequence of a briber's behavior functions as an antecedent for a bribee's behavior. Although both individuals receive their consequences, the reinforcement is mutual (Lindsley, 1963), because it depends on the cooperative action. This is a metacontingency conditional relation maintained by the contingencies of social transmission of culture (Holth, 2016).

As indicated earlier, the agents involved in this corrupt system are under the control of multiple possible contingencies of reinforcement. The briber gets his/her incomplete application approved promptly (positive reinforcement), but $\mathrm{s} / \mathrm{he}$ loses money (negative punishment). The bribee gets additional tax-free income (positive reinforcement) but avoids any negative sanctions because $\mathrm{s} / \mathrm{she}$ is not reported (negative reinforcement), more so because the oversight is part of the IBCs that generated the corrupt AP. At the metacontingency level, these IBCs ought to be recurrent in a manner they cannot be detected and punished. Thus, it may be described as a metacontingency (recurrence of IBCs and AP) maintained by negative reinforcement (avoiding the effects of law). The fact that corrupt metacontingencies are selected by negative reinforcement, may render it difficult to extinguish. Supposing the same consequences (timeliness in the processing of an application for the client and extra income for the officer due to an introduction of an internal bonus system) are obtainable through an online application system, the corrupt IBCs, all things being equal, may no longer be selected. Therefore, if the reinforcement is not contingent on concerted efforts (conditional relation in a metacontingency), the corrupt interaction will decrease in frequency. This kind of relation has been shown in experimental research (e.g., Azrin \& Lindsley, 1956; Tan \& Hackenberg, 2016; Vasconcelos \& Todorov, 2015).

In an incorrupt transaction, the client upon submitting an application would not offer any bribe and the public officer would not demand any bribe. The decision not to grant a business permit complied with the rules and regulations (compliance behavior has been selected) and executed by public servants who behave professionally during public encounters. The vigilance of a principled oversight (an ethical leader), interacts with the IBCs and APs. An ethical leader is someone who is concerned about the reputation of the organization (internally and externally and therefore demonstrates "appropriate conduct through personal actions and interpersonal relationships, and the promotion of such conduct to followers through two-way communication, reinforcement, and decision-making" (Brown et al., 2005, p.120). 
Culturant

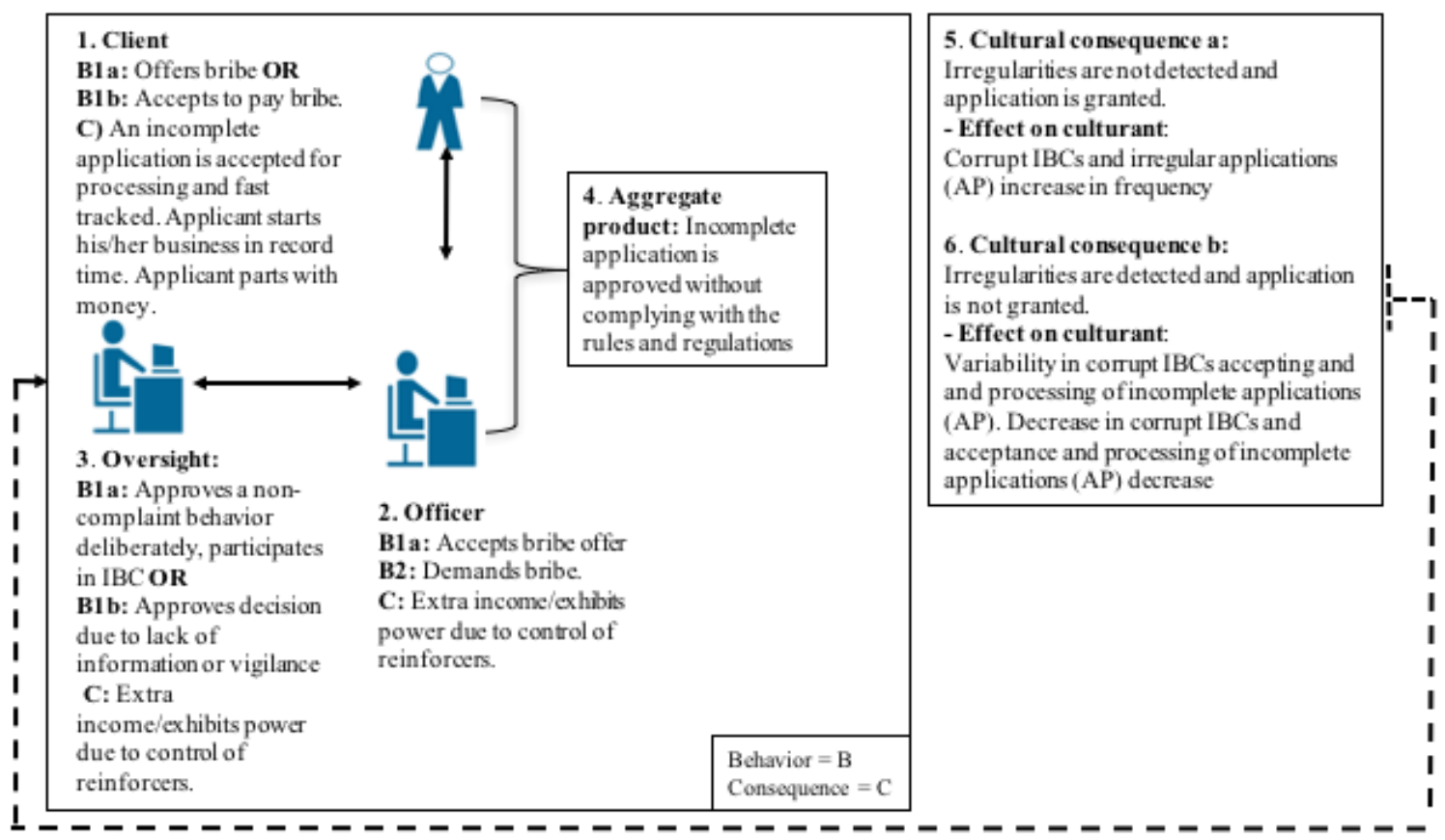

Figure 2. Corrupt/incorrupt IBCs - possible cuttural consequences

At the individual level, a client (1), a public officer (2) and an oversight person (3) engage (actively or passively) in corrupt transactions and their behaviors are reinforced. If all actors are involved in the IBCs, an incomplete application will be accepted for processing and fast tracked (4). However, the IBCs and the AP (case processing defying compliance rules) will only became recurrent if it is not detected by the system (5). However, if the irregularities are detected by the system (6) IBCs and AP may vary and/or decrease in frequency.

Relying on ethical leaders alone, however, may not be enough to change corruption as a cultural practice. The future gains of an incorrupt public encounter have to be made clear and marketed as reinforcers to agents. Being an employee in an organization reputed for timeliness in making decisions because the queue system is not distorted and the reputation of an organization which is not eroded by corruption, ought to be social reinforcers. Anecdotal evidence suggests that employees of Petrobrás tried to conceal their affiliation to the company during the height of the corruption scandal involving Petrobrás Macrocontingency

Sometimes the behavior of many individuals, having similar topographies, can come under the control of similar contingencies in which the product of the individual behavior creates an effect at the level of culture (Glenn, 2004). The concept of macrocontingency best explains the cumulative effects of the behaviors of many different individuals or different groups of individuals. It is a "Relation between (1) an operant behavior governed by individual contingencies and/or interlocking behavioral contingencies (IBCs) governed by metacontingencies and (2) a cumulative effect of social significance" (Glenn et al., 2016, p. 19). The agents participating in the corrupt IBCs are unarguably disconnected from the effects of the IBCs on the organization or society. A corrupt behavior will hardly constitute a social problem when a public officer demands or accepts a bribe once or twice during a public encounter. It will be an instance of a bad apple in a barrel (de Graaf, 2007). It becomes a social problem, however, when large numbers of individuals frequently give, demand, or accept bribes during these public encounters.

The cumulative effect of individual corrupt behaviors has an impact on the state and its institutions. The notorious scandals like Operation Anaconda, Operation Bloodsuckers, Petrobrás, and Operação Lava Jato and other "malfeasance by public officials, particularly in political parties, the legislature, and local governments" (Carson \& Prado, 2014, p. 14) have led to loss of confidence not only in Brazilian politicians and political parties, but also in corporate Brazil. Corruption could also erode a nation's international reputation. Using Ghana as an example, Figure 3 summarizes the 
cumulative effects of corruption. Capital flights, weakening of democracy, good governance, and poor quality of service delivery, are some cases in point (Ghana, 2011).

To sum up, we have provided behavioral contingency and metacontingency analyses of corruption. How do our analyses contribute to the understanding of corrupt behavior and its mitigation? In the three-term contingency, the first term (antecedent) and the third term

\begin{tabular}{|l|}
\hline $\begin{array}{l}\text { Corrupt IBCs government } \\
\text { agencv } 1\end{array}$ \\
Corrupt IBCs government \\
agency 2
\end{tabular}

(consequences of behavior) are the environmental factors that influence behavior. The middle term (behavior) is what is selected or the emitted behavior. To predict and change behavior, the focus should be on the first and the third terms, the environmental events influencing and maintaining the classes of behavior during corruptible actions.

\section{CUMULATIVE EFFECTS OF CORRUPTION ON THE GHANAIAN SOCIETY (Ghana, 2011, pp. 28-29).}

(a) Provision of poor quality services (in such areas as education, health, sanitation and electricity);

(b)Undermining or weakening of institutions for democracy and good governance;

(c) Loss of lives;

(d) Abandonment of development projects;

(e) Haphazard developments;

(f) Flight of capital;

(g) Increased costs of business;

(h) High cost of infrastructural development;

(i) Destruction of merit-based competition;

(j) Weakening of professionalism through production of the proverbial "square pegs in round holes";

(k) Destruction of the productive capacity and creativity of individuals (e.g. skilled and honest people remain unemployed); and (l) Facilitation of other criminal activities such as drug-trafficking, human-trafficking, terrorism, prostitution and money laundering.

Figure 3. The cumulative effect of many client-officer interlocked relationship on society.

In a metacontingency, the first term (IBCs) contributes to generating the aggregate product (the second term). The third term (the selecting environment or receiving system) is an environmental factor, which selects the IBCs and AP. Thus, changing the IBCs and AP of corruption requires measures at the level of groups, organizations and governmental agencies. Identifying and ending corruption at the level of society require a systemic approach, as the "cumulative effect in a macrocontingency is not actually in a contingent relation with the practices (individual or organizational). That is, the cumulative effect automatically results from the practices and is not independently manipulable" (Glenn et al., 2016, p. 20). To tackle the cumulative effects of behavioral contingency or metacontingencies, a variation upon which selection can operate is necessary. Consequently, it is expedient to establishan anti-corruption measures at multiple levels. We provide examples of how to mitigate corrupt behaviors identified as a behavioral contingency, metacontingency, and macrocontingency under the next heading.

\section{Towards a framework for interventions - some measures to mitigate corruption}

To tackle corruption at the individual level, one must begin by examining the contingencies that engender non-compliant or corrupt behavior, as well as contingencies that may support and maintain compliant behavior. If compliant behavior is the targeted behavior, one or more of 
the following strategies could be used to change behavior: (a) increasing reinforcement for targeted behavior; (b) decreasing aversive consequences for targeted behavior; (c) decreasing reinforcement for competing behaviors; and (d) increasing aversive consequences for competing behaviors (Biglan, 1995, p. 137). For example:

Fast-tracking applications at an additional cost may increase reinforcement for clients and consequently end the offering of bribes.

Offsetting officialdom's monopoly position over administrative actions by increasing the number of service delivery channels or through online application-procedures may increase client compliant behavior.

Increasing administrative literacy of clients. A client who is administrative illiterate ${ }^{3}$ is an easy "prey" for arrogant/corrupt bureaucrats (Peters, 1984). Officialdom in modern bureaucracy increasingly uses difficult and unfamiliar regulations when exercising authority (Ridley, 1979). The rules and regulations which, constitute the framework of their decisions may be incomprehensible for the common person. Administrative literacy therefore, might pay immediate dividends in fighting corruption, because an informed citizen would not be "left stammering incoherently" when s/he finally make it through the bureaucratic maze and stands face-to-face with the bureaucrat (Ridley, 1979, p.23).

Increasing administrative literacy of clients may help decrease the aversive consequences of encountering corrupt and bullying bureaucrats. When you know the rules, you may not succumb to extortion of bribes by public officers, all things being equal. Sensitizing and enhancing the administrative literacy of clients, especially the poor, on how to detect, respond and report fraud has been used as anti-corruption measures in Brazil. Bersch (2015, p. 207) observed that Instituto de Fiscalização e Controle (Institute of Auditing and Monitoring), through its outreach programs, travel to poorer municipalities to educate citizens on the basics of corruption and how to conduct civic audits in the health sector.

Discover, name, shame, and jail could be used to increase the aversive consequences of corrupt behavior. Mazar and Ariely (2006, p. 5) observe that "curbing dishonest behavior" at the individual level is a challenging affair, but offered two approaches: "the probability of being caught and the magnitude of punishment should be increased". The "ficha limpa" or the "clean sheet" law, in Brazil, disallows candidates with "dirty" court records (i.e.,

\footnotetext{
${ }^{3}$ Those who do not have knowledge of formal rules public officers apply in making decisions.
}

convicted by a second-level court) to run for offices ${ }^{4}$. Another example is the operation Bloodsucker (leech or sanguessuga), that recommended the expulsion (cassação) of seventy-two members of Congress (Praça, 2011). For the name, shame and jail to be an efficacious anti-corruption tool, however, a clean reputation ought to be considered as a prized social reinforcer in that verbal community. To be referred to as "dirty" must be punishing (aversive).

Arranging conditions to detect and report corrupt behavior. Laws like the "Right to Information" can embolden citizens to demand transparent public encounters. On reporting the fraudulent behavior of colleagues, research has shown that employees are willing to (a) caution and (b) report the corrupt behavior of co-workers only when reporting is part of their job description (Gorta \& Forell, 1995). Employment agreements with a behavioral contract component should unequivocally communicate to employees that they have a responsibility not to abjure but also report all forms of impropriety.

Anti-corruption agents should arrange conditions to deter corrupt practices, by making it extremely damaging and costly (Biglan, 1995) to engage in corrupt practices. Brazil passed the Clean Company Act (Lei Anti-Corrupcão) in 2013. Lack of law enforcement, however, may account for the prevalence of corrupt practices. Brazil has been praised in international circles for enforcing its anticorruption laws (Praça \& Taylor, 2014). The enforcement of anti-corruption laws should be prioritized, by resourcing law enforcement agencies.

Institutional multiplicity. The resolve to enforce laws in Brazil's anti-corruption campaign has been enhanced by the willingness on the part of anti-corruption agents to use other institutions than the judiciary, thanks to the multiplicity of institutions ${ }^{5}$. Prado, Carson, and Correa (2016), observed that anti-corruption agents circumvent the judiciary by actively using administrative procedures within the framework allowed by the Clean Company Law. Similarly, anti-corruption "crusaders" in Ghana have circumvented the Executive by subpoenaing a corrupt person or the government, where the Attorney General had been slow or reluctant to prosecute persons suspected of felonies, apparently because the suspects have been benefactors of the governing party.

\footnotetext{
4 "Both hypothetical and field experiments show that Brazilian voters are unlikely to change their choice of candidate, even after receiving information about the candidate's involvement in corruption schemes... In sum, the evidence does not indicate that the Brazilian voters effectively punish corrupt politicians in the voting booth" (Carson \& Prado, 2016, p. 61).

${ }^{5}$ Bodies within a defined institutional sphere with the capacity to investigate corruption cases, prosecute and punish corrupt offenders (Carson \& Prado, 2016).
} 
A selecting environment disturbing the corrupt IBCs. Corrupt behaviors are maintained by individual contingencies as well as metacontingencies. The corrupt IBCs and APs will continue because there are no disapproving feedbacks from an external environment. Therefore, there is the need for an ethical leader ${ }^{6}$ to monitor and provide feedback on the IBCs and APs.

Training of staff in compliance behavior and the promotion of desirable cultural practices is important. According to Biglan training should involve "instruction, modeling, reinforcement and feedback" (1995, p.168), Increasing reinforcement of targeted behavior or supportive practices through social reinforcement is advised. Officers and clients who comply with regulations should be given recognition publicly (Biglan, 1995).

Contact with the negative externalities of behavior. Corrupt agents should be put in contact with the deleterious consequences of their behaviors through educational means.

In addition to the above measures, anti-corruption agents should appreciate the beneficial outcomes of targeted (compliant) behavior, while endeavoring to reduce the detrimental outcomes of corrupt behavior or practices (Biglan, 1995). Contingencies that have ex-ante and ex-post concurrent qualities should be developed and refined because they have elements that prevent and monitor at the same time. An example of such a measure is the Random Audits Program (Programa de Fiscalização a partir de Sorteios Públicos), established in 2003 by the Office of the Controller General (Controladoria Geral da União or CGU). The CGU uses a lottery system to select randomly municipalities whose books are then audited to monitor the use of Federal Funds (Carson \& Prado, 2014).

To summarize, the first step toward fighting corruption is to identify the agent(s) involved, determine the antecedents and consequences of behavior for an individual, the IBCs and the resultant aggregate products in case of groups. Corruption as a culturant that involves three agents defined by the activities: paying a bribe, demanding a bribe, receiving a bribe, and providing oversight. Karklins (2005) asserts that if two of these agents have any reasons to change their behaviors (IBCs), combating corruption will not be as enigmatic as it has proven to be. For instance, where a client offers a bribe when accessing a public service, it should be possible to arrange contingencies to encourage the public officer to decline the bribe and report a client. The alliance between the management (oversight) and the public officer will compel the client to comply with the laws. In the behavioral category, where a public officer demands bribe as

\footnotetext{
${ }^{6}$ A leader who is a de facto embodiment of the compliance culture and reinforces behavior that promotes the reputation of the organization as clean and punishes behavior that dents the organization's image.
}

a condition to issuing a permit, an alliance between the management (oversight) and the client may compel the public officer to comply with the laws. In the instances where two of the agents decide to collude to engage in corrupt behaviors (exemplified by fraud cases), however, it is only the installation of ex ante and ex post contingencies such as routine and institutional controls, vigilance, transparency, counter checks by an oversight authority that will ensure compliance (de Graaf, von Maravić, \& Wagenaar, 2010).

\section{Concluding Remarks}

In this paper, we have discussed corruption from a behavior analytic perspective. Our conclusion after using operant and metacontingency analyses on corrupt behavior indicates that petty corruption (and for that matter grand corruption) can be understood as behavioral and cultural practices. We highlighted the environmental factors engendering and maintaining corruption. While, it is advantageous to use an operant analysis to explain a corrupt behavior, the concepts of metacontingency and macrocontingency enhance the operant analysis. A metacontingency exposes the interlocking behavioral contingencies of the briber and bribee. We suggest a further refinement of the analysis and exploration of the functional relation between the IBCs, the aggregate product and the selecting environment to study corruption. The growing body of experimental research on metacontingencies should be extended to investigate corrupt behaviors. How to resolve ethical dilemmas during public encounters could be a subject for future research. It may entail ethical self-control or selfmanagement to resolve such dilemmas, and the work of Borba, Tourinho, and Glenn (2014) on ethical self-control is worth mentioning in this regard. Many corruption scandals tend to involve the management level. The leader's role as an anti-corruption agent in changing a corrupt culture cannot be overemphasized. The role of leadership in ensuring compliance, with a focus on the construct "ethical leadership", is an area that deserves research attention. We call for applied research, especially research directed towards best practices in combating corruption by looking at topics like contingency contracting and self-ethical control and the role of leadership in changing corrupt organizational cultures.

\section{Compliance with Ethical Standards}

Funding: This study has not benefited from any funding from any corporate entities.

Disclosure of conflicts of interest: The authors have not received any funding or support that compromise our research.

Ethical declaration: We confirm that the article complies with the ethical guidelines and by the ethical standards as laid down in the 1964 Declaration of Helsinki and its later amendments. 


\section{REFERENCES}

Agbota, T. K. (Submitted). Petty corruption: A behavioral account of clients' encounter with regulators during public administrative actions. Ephemera: Theory and Politics in Organization.

Agbota, T. K., Sandaker, I., \& Ree, G. (2015). Verbal operants of corruption: A study of avoidance in corruption behavior. Behavior and Social Issues, 24, 126-148. doi: 10.5210/bsi.v24i0.5864

Azrin, N. H., \& Lindsley, O. R. (1956). Reinforcement of cooperation between children. Journal of Abnormal and Social Psychology, 52(1), 100-102. doi: http://dx.doi.org/10.1037/h0042490

Barr, A., \& Serra, D. (2010). Corruption and culture: An experimental analysis. Journal of Public Economics, 94(11-12), 862-869. doi: 10.1016/j.jpubeco.2010.07.006

Basu, K. (2011). Why, for a class of bribes, the act of giving a bribe should be treated as legal. Retrieved February 02, $2014 \quad$ http://mpra.ub.unimuenchen.de/50335/1/MPRA_paper_50335.pdf

Bersch, K. S. (2015). When democracies deliver: governance reform in Argentina and Brazil. (PhD), The University of Texas at Austin. Retrieved from https://repositories.lib.utexas.edu/handle/2152/32531.

Biglan, A. (1995). Changing Cultural Practices: A Contextualist Framework for Intervention Research. Reno, NV: Context Press.

Borba, A., Tourinho, E. Z., \& Glenn, S. S. (2014). Establishing the macrobehavior of ethical self-control in an arrangement of macrocontingencies in two microcultures. Behavior and Social Issues, 23, 68-86. doi: http://dx.doi.org/10.5210/bsi.v23i0.5354

Brasil. (2007). Lei $n^{\circ}$ 11.598, de 3 de dezembro de 2007. Brasília: Presidência da República. Retrieved from: http://www.planalto.gov.br/ccivil_03/_ Ato20072010/2007/Lei/L11598.htm

Breit, E., Lennerfors, T. T., \& Olaison, L. (2015). Critiquing corruption: A turn to theory. Ephemera: Theory and Politics in Organization, 15(2), 319-336. Retrieved from: https://oda.hioa.no/en/critiquing-corruption-aturn-to-theory-special-issue-editorial

Brown, M. E., Treviño, L. K., \& Harrison, D. A. (2005). Ethical leadership: A social

learning perspective for construct development and testing. Organizational

Behavior and Human Decision Processes, 97, 117-134.

Byrne, E. (Producer). (2009). Definitions and types of corruption. Retrieved from http://elaine.ie/2009/07/31/definitions-and-types-ofcorruption/

Carson, L., \& Prado, M. M. (2014) Mapping Corruption \& its Institutional Determinants in

Brazil. Vol. 08. IRIBA Working Paper. School of Environment, Education and Development, The University of Manchester, Oxford Rd, Manchester, M13 9PL: International Research Initiative on Brazil and
Africa (IRIBA).

Carson, L., \& Prado, M. M. (2016). Using institutional multiplicity to address corruption as a collective action problem: Lessons from the Brazilian case. The Quarterly Review of Economics and Finance, 62, 56-65.

CDD. (2000). Center for Democratic Development. The Ghana Governance and Corruption Survey. Evidence from Households, Enterprise and Public Officials. Accra: Centre for Democratic Development (CDD).

Cone, J. D., \& Hayes, S. C. (1984). Environmental problems/ behavioral solutions. Cambridge: Cambridge University Press.

Couto, K. C., \& Sandaker, I. (2016). Natural, behavioral and cultural selection-analysis: An integrative approach. Behavior and Social Issues, 25, 54-60. doi: 10.5210/bsi.v.25i0.6891

Daniels, A. C., \& Lattal, A. D. (2017). Life's a PIC/NIC... when you understand behavior.

Cornwall on Hudson, NY: Sloan Publishing.

de Graaf, G. (2007). Causes of corruption: Towards a contextual theory of corruption public

administration. Quarterly, 31, 39-86.

de Graaf, D. G., von Maravić, P., \& Wagenaar, P. (Eds.). (2010). The good cause: Theoretical

perspectives on corruption. Barbara Budrich Publishers.

Della Porta, D., \& Vannucci, A. (1999). Corrupt exchanges: Actors, resources, and mechanisms

of political corruption. New York, NY: Transaction Publishers.

Dwivedi, O. P. (1990) Administrative theology: Dharma of public officials. Indian Journal of

Public Administration, 36(3), 406-419.

Fein, E., \& Weibler, J. (2014). Review and shortcomings of literature on corruption in organizations in offering a multi-faceted and integrative understanding of the phenomenon Behavioral. Behavioral Development Bulletin, 19 (3), 67-77. Retrieved from: http://psycnet.apa.org/journals/bdb/19/3/67.pdf

Fernandes, D. M., Pezzato, F. A., \& Perallis, C. G. (2015). Creativity, Brazilian "jeitinho," and

cultural practices: A behavioral analysis. Behavior Analysis: Research and Practice, $1 \quad$ 5(1), 28-35. doi: http://dx.doi.org/10.1037/h0101067

Foxall, G. R. (2010). Interpreting consumer choice: the behavioral perspective model. London:

Routledge.

Ghana. (2011). National Anti-Corruption Plan (NACAP). Accra: Government of Ghana.

Glenn, S. S. (1986). Metacontingencies in Walden Two. Behavior Analysis and Social Action, 5,

2-8.

Glenn, S. S. (2004). Individual behavior, culture and social change. The Behavior Analyst, 27,

133-151. Retrieved from: https://www.ncbi.nlm.nih.gov/pmc/articles/PMC275539 6/ 
Glenn, S. S., Malott, M. E., Andery, M. A. P. A., Benvenuti, M., Houmanfar, R. A., Sandaker, I.

.. \& Vasconcelos, L. A. (2016). Toward Consistent Terminology in a Behaviorist Approach to Cultural Analysis. Behavior and Social Issues, 25, 11-27. Doi: http://dx.doi.org/10.5210/bsi.v25i0.6634

Golden, M. A. (2012). Corruption in the Wealthy World. The Brown Journal of World Affairs,

$21 \quad(5)$, doi:https://doi.org/10.1177/1354068813491540

Goldiamond, I. (1975). Alternative sets as a framework for behavioral formulations and

Research. Behaviorism, 3(1), 49-86.

Goldstein, M. K., \& Pennypacker, H. S. (1998). From candidate to criminal: The contingencies of

corruption in elected public office. Behavior and Social Issues, $\quad 8, \quad 1-8 . \quad$ doi: http://dx.doi.org/10.5210/bsi.v8i1.317

Goodsell, C. T. (1981). The Public encounter: where state and citizen meet. Bloomington, IL: I

Indiana University Press.

Gorta, A., \& Forell, S. (1995). Layers of decision: Linking social definitions of corruption and

willingness to take action. Crime, Law and Social Change, 23(4), 315-343. doi: 10.1007/BF01298447

Holth, P. (2016). Levels of selection: A place for cultural selection. Norsk Tidsskrift for Atferdanalyse, 43(1), 5764.

Johnston, M. (1997). Public officials, private interests, and sustainable democracy: When politics and corruption meet. Corruption and the Global Economy, 83, 67.

Karklins, R. (2005). The system made me do it: corruption in post-communist societies. Armonk, NY: M.E. Sharpe.

Klitgaard, R. E. (1988). Controlling corruption. Berkeley, CA: University of California Press.

Köbis, N. C., van Prooijen, J.-W., Righetti, F., \& Van Lange, P. A. M. (2016). Prospection in individual and interpersonal corruption dilemmas. Review of General Psychology, 20(1), 71-85. doi: http://dx.doi.org/10.1037/gpr0000069.

Le Vine, V. (1975). Corruption in Ghana. Transition, 47, 48-61.

Lindsley, O. R. (1963). Social reinforcement and behavior change-Symposium, 1962: 4. Experimental analysis of social reinforcement: Terms and methods. American Journal of Orthopsychiatry, 33(4), 624.

Malagodi, E. F., \& Jackson, K. (1989). Behavior analysts and cultural analysis: Troubles and issues. The Behavior Analyst, 1(12), 17-23. Retrieved from: https://www.ncbi.nlm.nih.gov/pmc/articles/PMC274202 5/

Martin, G., \& Pear, J. (2009). Behavior modification: What it is and how to do it. (8th Ed.).

Upper Saddle River, NJ: Pearson Prentice Hall.

Mazar, N., \& Ariely, D. (2006). Dishonesty in everyday life and its policy implications. Working
Paper Series. Boston: Federal Reserve Bank.

Mishra, A. (2005). The persistence of corruption: some theoretical perspectives. World

Development, $\quad 34(2), \quad 349-358 . \quad$ Doi: 10.1016/j.worlddev.2005.03.010

Nuijten, M., \& Anders, G. (2007). Corruption and the secret of law: a legal anthropological

perspective. Aldershot, Hants, England: Ashgate.

Pedersen, K. H., \& Johannsen, L. (2005). Corruption: commonality, causes \& consequences

comparing 15 ex-communist countries. Retrieved from http://unpan1.un.org/intradoc/groups/public/documents/ NISPAcee/UNPAN021456.pdf

Peters, B. G. (1984). The politics of bureaucracy. New York, NY: Longman.

Power, T. J., \& Taylor, M. M. (2011). Corruption and democracy in Brazil. Notre Dame, PI:

University of Notre Dame Press.

Praça, S. (2011). Corrupção e reforma institucional no Brasil, 1988-2008. Opinião Pública,

17(1), 137-162. doi: http://dx.doi.org/10.1590/S010462762011000100005

Praça, S., \& Taylor, M. (2014). Inching toward accountability: The evolution of Brazil's

anti-corruption institutions, 1985-2010 (Vol. 56 (2) Latin American Politics and

Society. $\quad$ http://www.sergiopraca.com/wpcontent/uploads/2015/05/Corrup-2.pdf

Prado, M. M., Carson, L. D., \& Correa, I. (2016). The Brazilian Clean Company Act: using

institutional multiplicity for effective punishment. Osgoode Legal Studies Research

Paper Series 119. Osgoode Hall Law School.

Rabl, T., \& Kühlmann, T. M. (2008). Understanding corruption in organizations - development

and empirical assessment of an action model Journal of Business Ethics, 82(2), 477-495. doi: 10.1007/s10551008-9898-6

Ridley, F. F. (1979). Government and administration in Western Europe. Oxford, OXON: Martin Robertson.

Rose-Ackerman, S. (1999). Bribes, patronage, and gift giving. Corruption and government: causes, consequences, and reform. Cambridge, CAMBS: Cambridge University Press.

Rothstein, B., \& Varraich, A. (2014). Corruption and the opposite to corruption. A map of the conceptual landscape. ANTICORRP, WP, 1. Retrieved January 12, 2015 http://anticorrp.eu/publications/corruption-andthe-opposite-to-corruption-a-map-of-the-conceptuallandscape/

Sandaker, I. (2006). How should behavior analysis interact effectively with the social sciences? Behavior and Social Issues, 15, 81-92. doi: http://dx.doi.org/10.5210/bsi.v15i1.346

Sandaker, I. (2009). A selectionist perspective on systemic and behavioral change in organizations. Journal of 
Organizational Behavior Management, 29(3-4), 276293. doi: http://dx.doi.org/10.1080/01608060903092128

Skinner, B. F. (1953). Science and human behavior. New York, NY: Macmillan.

Skinner, B. F. (1981). Selection by consequences. Science, 213, 501-504. doi: 10.1126/science.7244649

Tan, L., \& Hackenberg, T. D. (2016). Functional analysis of mutual behavior in laboratory rats (Rattus norvegicus). Journal of Comparative Psychology, 130(1), 13-23. doi: $10.1037 / \mathrm{com} 0000015$

Todorov, J. C. (2006). The metacontingency as a conceptual tool. Behavior and Social Issues, 15(1), 92. doi.org/10.5210/bsi.v15i1.347

Transparency International. (2016). Corruption Perceptions Index (2016). Retrieved from http://www.transparency.org/news/feature/corruption_pe rceptions_index_2016.

Uslaner, E. M. (2008). Corruption, inequality, and the rule of law: the bulging pocket makes the easy life. Cambridge, CAMBS: Cambridge University Press.

Vasconcelos, I. G., \& Todorov, J. C. (2015). Experimental analysis of the behavior of persons in groups: selection of an aggregate product in a metacontingency. Behavior and Social Issues, 24, 111-125. doi: http://dx.doi.org/10.5210/bsi.v24i0.5424

World Bank. (2017). What is fraud and corruption? Retrieved April 24, 2017, from World Bank http://www.worldbank.org/en/about/unit/integrity-vicepresidency/what-is-fraud-and-corruption

Submitted: $21 / 012017$

Approved: 09/07/2017 